University of Tennessee Law

Legal Scholarship Repository: A Service of the Joel A. Katz Library

UTK Law Faculty Publications

$3-2018$

Splitsylvania: State Secession and What to Do About It

Glenn Harlan Reynolds

Follow this and additional works at: https://ir.law.utk.edu/utklaw_facpubs

Part of the Law Commons 


\title{
SPLITSYLVANIA: STATE SECESSION AND WHAT TO DO ABOUT IT
}

\author{
Glenn Harlan Reynolds*
}

INTRODUCTION

From Is New California Unconstitutional? A Centennial Reflection, 210 CALIF. L. ReV. 1 (2122):

Brace yourselves for this one, Desert Riders. New California might not legitimately be a State of the Union, but a mere illegal breakaway province of the State of California.

In the summer of 2021, following the California financial crisis and CalPers pension collapse, public employee-supporting Democrats from the California General Assembly absented themselves from the state, preventing a quorum so that legislation slashing pension payouts could not be passed. That absence stretched from days into weeks, as the state government largely shut down for lack of funding. Seizing on this moment, thirty-four counties from the eastern and rural parts of what was then California organized themselves and sent representatives to Fresno, where those representatives declared themselves the new, official California General Assembly and designated individuals of their choice as the new, official Governor and Attorney General.

The new legislature and officials were quickly recognized by President Trump, who, citing his authority under the Insurrection Act and Article IV, Section 4 of the U.S. Constitution, deemed them the official government of the state, and sent federal troops from the 101st Airborne Division to Fresno to ensure that what he called "leftovers" of the "old, failed state government" were unable to "cause trouble." President Trump's recognition was echoed in a joint resolution of the Republican-controlled Congress, which perhaps anticipated the addition of two new Republican Senators.

Immediately thereafter, the now duly recognized California legislature in Fresno petitioned Congress to be allowed to split California into two states. A narrow coastal strip extending from Los Angeles County in the South to Sonoma County in the North would remain the state of California; the rest would become the new

(C) 2019 Glenn Harlan Reynolds. Individuals and nonprofit institutions may reproduce and distribute copies of this Essay in any format, at or below cost, for educational purposes, so long as each copy identifies the author, provides a citation to the Notre Dame Law Review Online, and includes this provision and copyright notice.

* Beauchamp Brogan Distinguished Professor of Law, University of Tennessee. J.D. Yale Law School; B.A. University of Tennessee. Thanks to Daniel Ames for excellent research on this Essay. 
state of New California. Congress, at the President's recommendation, immediately approved this change, and the state of New California was born. (Acquiescence to this scheme, the prior government of California was told, was a prerequisite to any federal bailout, but judicial review seemed unlikely anyway, as the Supreme Court had already held federal recognition of state governments to be a political question as far back as Luther v. Borden ${ }^{1}$ ).

But could they do this? Was this change - though literally within the wording of the Constitution-legitimate? Well, there is the precedent of West Virginia to consider.

This "future history"-borrowing heavily in places from Vasan Kesavan and Michael Stokes Paulsen's Is West Virginia Unconstitutional? ${ }^{2}$ - is farfetched. ${ }^{3}$ But the larger issue of intrastate secession is a growing one, and it would be helpful to address it, and perhaps to relieve the pressure, before things reach a more difficult pass.

In fact, intrastate secession is the true secession fever: not the perennial postelection calls of losing parties to secede from a nation controlled by the opposition, but a growing movement for secession from states, with the rural parts of states (sometimes geographically very large parts of states) wanting to separate from the population-dense urban areas that essentially control state decisionmaking. Feeling ignored, put-upon, and mistreated, secessionists want to take their fate into their own hands. These movements are common, but not likely to succeed on their own, as intrastate secession is, though not entirely unknown (see, e.g., West Virginia), very difficult to achieve.

But these movements do indicate a widespread sense of dissatisfaction among (mostly rural) populations who feel that they are governed by people in distant urban centers who know little, and care less, about their way of life. Such sentiments, which in a way resemble those regarding Britain in the lead-up to the American Revolution, ${ }^{4}$ have probably worsened since the Supreme Court's line of cases beginning with Baker v. Carr ${ }^{5}$ weakened rural areas' political position in favor of urban areas. This problem was, to a degree, foreseen by contemporary critics of those decisions. ${ }^{6}$

\footnotetext{
148 U.S. (7 How.) 1 (1849).

2 Vasan Kesavan \& Michael Stokes Paulsen, Is West Virginia Unconstitutional?, 90 CALIF. L. REV. 291 (2002).

3 While the future history is fiction, the New California movement is real. See infra Part I.

4 See Gordon S. WoOd, Representation In THE AMERICAN REVOlution 10 (rev. ed. 2008). Colonists argued that members of Parliament were faraway "perfect strangers" to America, who were "not bound in interest, duty, or affection" to Americans. Id. (citations omitted).

5 See, e.g., Reynolds v. Sims, 377 U.S. 533 (1964) (holding that unlike federal government, state governments are constitutionally forbidden from apportioning seats on basis other than population); Baker v. Carr, 369 U.S. 186 (1962) (finding that state redistricting presents a justiciable question).

6 See, e.g., Philip B. Kurland, Foreword: "Equal in Origin and Equal in Title to the Legislative and Executive Branches of the Government," 78 HARV. L. REV. 143, 156 (1964). Kurland characterized Warren Court jurisprudence as using equality to force uniformity. See id. In the context of Reynolds $v$. Sims, he observed: "To a Court determined to make population the sole standard on the theory of majority rule, all other factors become irrelevant." Id.
} 
In this short Essay, I will describe the problem, and suggest some ways in which - without overturning existing Supreme Court precedent or engaging in the sort of constitutional brinksmanship described above-Congress might remedy this dissatisfaction. Though there is no particular reason why the number of states in the United States should remain fixed at fifty, I will suggest that there are, in fact, remedies short of secession. The result of addressing these concerns, I hope, will be a less-polarized and angry national politics, and perhaps a smaller chance of serious turmoil.

\section{THE PROBLEM}

Intrastate secession is not exactly new in the United States: West Virginia was once part of Virginia, for example, ${ }^{7}$ and Tennessee was once part of North Carolina, though that evolution was less fraught. ${ }^{8}$ But in recent years we have seen a number of states facing calls to split, from inhabitants of regions who feel effectively unrepresented.

In New York State, for example, there have been repeated calls to split upstate New York from the New York City region. One such proposal involves letting the New York City area keep the name "New York," while the new upstate state would be named "New Amsterdam." The reason? "We're completely overwhelmed ... by the policies of New York City," according to New York State Senator Joseph Robach. ${ }^{10}$ The idea has been circulating for over twenty-five years, ${ }^{11}$ but now seems to be gaining some degree of additional support.

Perhaps better publicized is Silicon Valley entrepreneur Tim Draper's plan to split California into six states, one of which would be, essentially, Silicon Valley's own preserve. $^{12}$ Though Draper's plan did not make the 2016 ballot, ${ }^{13}$ it served as a useful outlet for complaints about unrepresented parts of the state. Draper explained his initiative this way:

7 See generally Kesavan \& Paulsen, supra note 2.

8 Inhabitants of the counties west of the Appalachians attempted to secede from North Carolina and form their own State of Franklin, which failed, but upon ratifying the Constitution in 1789 , North Carolina ceded those territories to the federal government, which recognized the state of Tennessee in 1796. Tre Hargett, SeC'Y of State, Tennessee Blue BooK 2017-2018, at 547-51 (2017).

9 Justin Moore, Could New York Become Two Separated States?, WKBW (May 14, 2016), http://www.wkbw.com/news/new-york-could-become-two-separated-states.

10 Jill Terreri, Splitting New York State?, N.Y. STATE SENATE (Dec. 23, 2009) (omission in original), https://www.nysenate.gov/newsroom/in-the-news/joseph-e-robach/splitting-new-yorkstate (statement of Sen. Joseph Robach).

11 Id. ("The idea has been around the state Legislature at least since 1991.").

12 Gregory Ferenstein, Tim Draper Wants to Split California into Pieces and Turn Silicon Valley into Its Own State, TECHCRUNCH (Dec. 19, 2013), https://techcrunch.com/2013/12/19/timdraper-six-californias-secede-silicon-valley-ballot-initiative/; see also Philip Bump, There's a Plan to Split California into 6 States. Here's What It Might Look Like, WASH. Post (July 15, 2014), https://www.washingtonpost.com/news/the-fix/wp/2014/07/15/theres-a-plan-to-split-californiainto-6-states-heres-what-it-might-look-like/?utm_term=.9ed7b8c22766.

13 Laura Mandaro, 'Six Californias' Fails to Make California Ballot, USA TODAY (Sept. 12, 2014), https://www.usatoday.com/story/news/nation-now/2014/09/12/six-californias-failsballot/15534081/. 
1. It is about time California was properly represented with Senators in Washington. Now our number of Senators per person will be about average.

2. Competition is good, monopolies are bad. This initiative encourages more competition and less monopolistic power. Like all competitive systems, costs will be lower and service will be better.

3. Each new state can start fresh. From a new crowd sourced state flower to a more relevant constitution.

4. Decisions can be more relevant to the population. The regulations in one new state are not appropriate for another.

5. Individuals can move between states more freely. ${ }^{14}$

Some such initiative might also please the residents of inland and northern California, who feel that the California state government-with its heavy interests in the Los Angeles and San Francisco areas_-views them with indifference or even hostility. ${ }^{15}$ Writing in the Los Angeles Daily News, demographer Joel Kotkin compared these neglected, poverty-stricken regions of California to apartheid-era South Africa's "Bantustans," observing:

Fresno, Bakersfield, Ontario and San Bernardino are rapidly becoming the Bantustans - the impoverished areas designed for Africans under the racist South African regime - in California's geographic apartheid. Poverty rates in the Central Valley and Inland Empire reach over a third of the population, well above the share in the Bay Area. By some estimates, rural California counties suffer the highest unemployment rate in the country; six of the 10 metropolitan areas in the country with the highest percentage of jobless are located in the central and eastern parts of the state. The interior counties - from San Bernardino to Merced-also suffer the worst health conditions in the state.

This disparity has worsened in recent years ....

But state policies, notably those tied to Gov. Jerry Brown's climate jihad, suggests Inland Empire economist John Husing, have placed California "at war" with blue-collar industries like homebuilding, energy, agriculture and manufacturing. These kinds of jobs are critical for regions where almost half the workforce has a high school education or less.

$$
\cdots
$$

Weighed down by coastal-imposed regulations, the interior is losing its allure for relocating firms. Many firms fleeing regulation, high taxes and housing costs used to head inland. Now, many are migrating to Nevada, Texas, Arizona and other states. 16

Outweighed by the population centers on the coast, and with that dominance undiluted by the geographic districting banned in Baker v. Carr and Reynolds $v$. Sims, inhabitants of these "Bantustans" are unable to obtain relief via democratic politics. Under Draper's plan, they would enjoy self-government and would be able

14 Ferenstein, supra note 12 (quoting Tim Draper, a California entrepreneur).

15 Joel Kotkin, The Other California: A Flyover State Within a State, L.A. DAILY NEwS (Apr. 10, 2017), http://www.dailynews.com/opinion/20170410/the-other-california-a-flyoverstate-within-a-state-joel-kotkin.

16 Id. 
to choose whether to live under the sort of arrangements that find support along the coast, or something different.

Somewhat less ambitious is a plan (the basis for the future history above) to split the wealthy coastal regions of California from the remainder, leaving the state of "New California" to be made up of most of the state's rural areas. As CBS News reports:

[U]nlike other separation movements in the past, the state of New California wants to do things by the book, citing Article 4, Section 3 of the U.S. Constitution and working with the state legislature to get it done, similar to the way West Virginia was formed.

$\cdots$

The group is organized with committees and a council of county representatives, but say it will take 10 to 18 months before they are ready to fully engage with the state legislature. ${ }^{17}$

The goal is to let the rural areas govern themselves in ways more suited to their needs, while the wealthy coastal regions do the same.

A similar dynamic obtains in Washington State, where some legislators are reviving a proposal, dating back to 1915 , to separate Eastern Washington into its own state, provisionally named "Liberty" 19

The political divide has only increased in recent years. The western part of the state, particularly the Seattle area, has supported initiatives legalizing marijuana and same-sex marriage and expanding gun background checks, proposals opposed by the majority of Eastern Washington voters.

"Urbanization and rapid growth in the western portion of Washington state have progressively heightened this divergence of cultural and economic values from that of the eastern portion of the state," the bill says.

The new bill is also sponsored by Reps. Matt Shea of Spokane Valley and David Taylor of Moxee.

The task force the bill seeks to create would look at the legal and political processes for making a boundary change, according to the bill's text. The task force would determine whether the states would be divided along existing county

17 New California Declares “Independence” From Rest of State, CBS NEWS (Jan. 16, 2018), https://www.cbsnews.com/news/new-california-declares-independence-from-rest-of-

state/?ftag $=\mathrm{CNM}-00-10 \mathrm{aab} 7 \mathrm{e} \&$ linkId $=47001582$ [hereinafter $\mathrm{New}$ California Independence]. The New California movement has a website, featuring proposed maps, declarations, and grievances. New California: The 51st State, NEW CAL. STATE, https://newcaliforniastate.com (last visited Dec. 30, 2018).

18 New California Independence, supra note 17.

19 Jim Camden, Matt Shea, Bob McCaslin Propose Creating New State Called "Liberty" in Eastern Washington, SPOKESMAN-REV. (Dec. 7, 2016), http://www.spokesman.com/stories/2016/dec/07/matt-shea-bob-mccaslin-propose-creating-newstate-/; see also Geoff Folsom, Tri-City Legislators Want Eastern Washington to Secede from the State, TRI-CITY HERALD (Jan. 28, 2015), http://www.tri-cityherald.com/latestnews/article32213466.html. 
lines or newly drawn lines. It would also have to consider issues like dividing up the tax bases, prison beds and transportation systems. ${ }^{20}$

Next door in Oregon, similar sentiments are at play. Like Washington State, Oregon is divided, "geographically, culturally, and politically," by the Cascade Range, with the urban, liberal, environmentally conscious western coastal region setting policies that find little favor across the mountains in the blue-collar eastern part of the state, where industries revolve around things like farming, ranching, and mining. ${ }^{21}$ That creates a sharp divide. As one Oregon resident explained, "[r]ural Oregonians ... . see Portland as an alien entity. Portland sees rural Oregonians as a bunch of hayseeds dragging their knuckles on the ground." ${ }^{22}$ As others have observed:

The skepticism is based on a simple principle: democratic local control is better than ignorant distant bureaucracy. Urban progressives shouldn't have trouble grasping this because it cuts both ways. Elitists in the cities are no more capable of competently running rural affairs than a bunch of ranchers could effectively micromanage urban affairs from the middle of nowhere.

Eastern Oregon's resistance to environmental activists is based partly on this leave-me-alone libertarianism and partly on the fact that many people use the land to earn a living - and also, perhaps, on how the environment affects human beings differently on each side of the mountains. Western Oregon's climate is wet in the winter but relatively comfortable all year, even during heat waves and cold snaps. The climate in Eastern Oregon is harsher. "I grew up 18 miles outside of Bend in the era before cell phones," [journalist Mark Hemingway] says, "and if your car breaks down on the wrong road in the wrong time of the year at the wrong time of night in four feet of snow, you might die. People out there have more of a nineteenth-century naturalist view of nature, where you have to respect it and also fear and loathe it when necessary.",23

Unsurprisingly, laws based on one worldview do not often sit well with people who entertain the other. In Oregon, this has led to calls for Eastern Oregon to secede from the state, among other things. ${ }^{24}$ Advocates propose perhaps joining Idaho, a state with which Eastern Oregon has more in common.

20 Folsom, supra note 19 (quoting H.R. 1818, 64th Leg., Reg. Sess. (Wash. 2015)).

21 Michael J. Totten, Fractured West, CITY J. (Dec. 31, 2017), https://www.cityjournal.org/html/fractured-west-15611.html.

22 Id.

$23 I d$. (quoting journalist Mark Hemingway).

24 See Grant Darrow, Is It Time for Eastern Oregon to Secede From the State?, ARGUS OBSERVER (June 23, 2015), http://www.argusobserver.com/opinion/is-it-time-for-rural-oregon-tosecede-from-the/article_3cd77c2e-19c8-11e5-a7bf-8b0f949373cc.html; see also Anna Griffin, Far-Fetched as They Might Seem, Secession Movements Are Thriving in the Pacific Northwest, OPB (Mar. 23, 2017), https://www.opb.org/news/article/pacific-northwest-secession-state-ofjefferson-cascadia/ (describing multiple secession movements, including one to combine a large portion of the Pacific Northwest, including eastern Washington and eastern Oregon, into a region called "Cascadia," with state flags already selling out).

25 Jade McDowell, Eastern Oregon Man Calls for Secession to Idaho, IDAHO PRESS (Sept. 26, 2015), https://www.idahopress.com/news/state/eastern-oregon-man-calls-for-secession-toidaho/article_a80df4b4-640a-11e5-a5f2-ab7c588ac148.html. 
There is even talk about splitting downstate Illinois away from Chicagoland. ${ }^{26}$ Once again, the downstate hinterland contains a lot of people (but, despite their much greater geographic extent, fewer in population than the Chicago metro area) who feel unrepresented, and believe that Chicago's dominance of the state causes downstate tax dollars to flow toward politicians' vote-buying efforts in Chicago.

These secession movements are not likely to be firing on Fort Sumter, or whatever the modern equivalent is, anytime soon. But we live in a time when centrifugal forces seem to be testing centripetal ones (note the recent efforts at Scottish and Catalonian independence, for example), and the presence of these secessionist sentiments is an indication that people in the hinterlands feel poorly served by majoritarian political systems. Historically, such sentiments tend to fester and sometimes erupt in violence. Is that something that can be fixed?

I think that it can. The straightforward - though not easy-approach would be to just split these states up: Washington and Oregon (and maybe New York and Illinois) into two states, California into two, five, or six depending on your plan. Of course, under Article IV, Section 3 of the Constitution, it is not as easy as that:

New States may be admitted by the Congress into this Union; but no new State shall be formed or erected within the Jurisdiction of any other State; nor any State be formed by the Junction of two or more States, or Parts of States, without the Consent of the Legislatures of the States concerned as well as of the Congress.

Legislative consent, required at both the state and federal levels, is likely to be difficult to get, barring unusual developments like a state financial breakdown. California's political leadership, for example, likely enjoys running a large and wealthy state. Breaking it into several states would diminish that. ${ }^{28}$ And in the case of California, and particularly Illinois, federal legislators might have leverage to promote a breakup in exchange for federal financial bailouts, should those become necessary.

At the national level, breaking up states is likely to affect the balance in the U.S. Senate, meaning that it will almost always be opposed by whichever party stands to lose from it. A sufficient Senate majority by one party might overcome that problem, but it would be an enormously contentious issue. Even legislators who stood to gain politically might worry about the precedent. Would another party split states further to change the balance again? The need for state legislators to approve another split would provide some sort of a limit, but how much?

At any rate, it should be possible to alleviate many of these problems without taking such a drastic step. In the remainder of this Essay, I will sketch out a number

26 Rich Miller, Does Rauner Want Downstate to Secede?, CRAIN'S CHI. BuS. (June 17, 2016), http://www.chicagobusiness.com/article/20160618/ISSUE11/306189991/does-raunerwant-downstate-to-secede; see also Kim Geiger et al., Rauner Rips 'Chicago Bailout' as Overtime Jockeying on Budget Begins, CHI. TRIB. (June 1, 2016), $\mathrm{http}$ //www.chicagotribune.com/news/local/politics/ct-illinois-budget-rauner-madigan-met-060220160602-story.html.

27 U.S. CONST. art. IV, § 3.

28 On the other hand, while California currently has one Governor, one Chief Justice, one Attorney General, etc., a broken-up California might have six such offices, giving more politicians an opportunity to be big fish, at the cost of dwelling in smaller, though still sizable, ponds. 
of proposals, some of them surprisingly simple, at both the state and federal levels, for addressing the underlying concerns.

\section{SOLUTIONS}

One seemingly obvious solution_-overturning the Supreme Court's decisions in Baker v. Carr and Reynolds v. Sims ${ }^{29}$ - is unlikely to be a solution at all. Even if the Court were inclined to reverse those decisions, which it shows no sign of being, doing so would not return things to the status quo ante. Under the post-Baker districting system, it would be urban legislators wielding the most power in any redistricting effort. That egg would be difficult indeed to unscramble. ${ }^{30}$

Nonetheless, there are things that both Congress and the states can do. Where Congress is concerned, the careful use of federal legislative powers, especially in sensitive areas like environmental and labor law, might restore to rural areas a sufficient degree of autonomy that secessionist sentiments, and general unhappiness, might be substantially reduced. In short, federal law often preempts state law on various grounds, and I suggest local autonomy as one more.

Federal laws regulating wages, working conditions, firearms, and environmental matters generally allow for states to pass more stringent laws governing themselves, in respect of state autonomy. But where the population of states is unevenly distributed, so that inhabitants of rural regions are effectively unrepresented, the autonomy thus preserved is lopsided. It is, in essence, the autonomy of a majority to make laws that an effectively unrepresented minority finds oppressive.

The federal government's legislative role has traditionally been the opposite: to use (as in the case of the 1964 Civil Rights Act) a national majority to ensure that local majorities cannot oppress local minorities. I thus suggest that federal laws regulating these key subject-matter areas be recast to preempt more restrictive state laws, meaning that urban areas would be unable to impose stricter laws on lesspowerful rural areas. If this seems too inflexible, perhaps that preemption should in some cases be defeasible at the county level. If the government of a county affirmatively wants to accept stricter state regulations, then it may do so; but if not, then the federal regulations are a ceiling, as well as a floor.

Given the expansive reach of federal legislative power today, states would have difficulty challenging this approach as beyond federal authority. ${ }^{31}$ And given the federal government's traditional role, since the adoption of the Civil War Amendments, of protecting local minorities from oppression by local majorities, such an approach is not that much of a departure. It might even find support in an earlier part of the Constitution, the Guaranty Clause of Article IV, Section 4, which

29 See supra notes 5-6 and accompanying text.

30 Likewise, it is possible that Congress has power to legislate geographic districting under its Guaranty Clause powers (I have a proof for this proposition, but it is too large to fit in the margin) but even so, the district-drawing would be done by the states' current power structures. It is not impossible to imagine a federal legislative solution to this, but I think it is fair to call such a solution vanishingly unlikely.

31 In some cases, the requisite preemption could probably be accomplished via administrative regulations. 
provides that the United States "shall guarantee to every State in this Union a Republican Form of Government.",32

The Guaranty Clause is generally regarded (though perhaps wrongly) ${ }^{33}$ as providing no basis for judicial action, but it is listed among the powers of Congress as they relate to the states, and seems to grant sufficient legislative power for Congress to protect local interests from exploitation and domination at the hands of legislative representatives who do not represent them. As mentioned earlier, such complaints regarding the British Parliament and its domination of the American colonies were a centerpiece of the American Revolution, with deep resentment regarding rule by faraway representatives who did not share in the circumstances or values of the ruled. $^{34}$ It is difficult to imagine the Framers regarding such domination by distant elites as part of a legitimately Republican form of government. What Congress would be doing here can be seen as a form of representationreinforcement, using John Hart Ely's phrase, ${ }^{35}$ to protect legislative minorities from unwarranted harm.

Indeed, the position of rural districts in heavily urbanized states looks very much like another classic case of representation-reinforcement in which "more searching judicial inquiry" is justified where legislation targets "discrete and insular minorities" and where ordinary political processes seem unlikely to provide relief. ${ }^{36}$ Inhabitants of rural parts of heavily urbanized states often have very different values and lifestyles, are generally stigmatized by the urban ruling class as "hicks" "rubes" and "rednecks," and lack comparable access not only to political power, but to media and other avenues that might be used to challenge the majority. Because their lifestyles and economic base are sharply different from inhabitants of urban areas, legislation that oppresses them can be enacted with limited impact on urban inhabitants.

These characteristics argue both for a congressional power to protect rural inhabitants against local majorities, and also for judicial evaluation, both of state laws and of federal remedies, conducted so as to keep this dynamic in mind. But there are also things that states can do, if they wish to limit secessionist sentiment.

There is nothing to stop a state from being mindful of the differences between urban and rural areas when crafting legislation or regulations. States could adopt a local-option regulatory scheme relating to key subject areas on their own, and by doing so would lighten their footprint in rural areas and lessen the likelihood of festering resentments. It is possible that urban voters would resist this, but it seems equally likely that they might have little enough knowledge of, or interest in, conditions in rural areas that no significant resistance is forthcoming.

\footnotetext{
32 U.S. CONST. art. IV, $\S 4$.

33 See New York v. United States, 505 U.S. 144, 184-85 (1992) (suggesting that not all issues under Guaranty Clause are nonjusticiable (citing Reynolds v. Sims, 377 U.S. 533, 582 (1964))).

34 See supra note 5 and accompanying text.

35 See generally John Hart Ely, Democracy And Distrust: A THEORY Of Judicial REVIEW (1980).

36 United States v. Carolene Prods. Co., 304 U.S. 144, 153 n.4 (1938).
} 


\section{CONCLUSION}

The rise of New California after a California state financial crisis remains unlikely. But if the federal government - and perhaps that of California as wellcan maintain a degree of sensitivity, it may also be made unnecessary.

State secession movements may never go away entirely, but relatively modest efforts may cause them to lose most of their salience. In this short Essay, I have argued that allowing different standards for urban and rural areas in key subjectmatter areas, something that can be done by both state and federal governments without any constitutional changes, is likely to accomplish that goal. I believe that little of value would be lost by this approach, and much, potentially, might be saved. 